\title{
PATHOLOGICAL STUDIES ON THE OSTEORENAL SYNDROME IN THE DOG
}

\author{
Shigeru IaHrJo \\ Department of Veterinary Internal Medicine, Obihiro Zootechnical University, Obihiro
}

(Received for Publication May 10, 1966)

The osteorenal syndrome is of great medical significance, including changes associated with lesions in the kidney, parathyroid, and bone. Of the research workers in this field, Askanazy ${ }^{3}$ ) was the first to recognize the causality between the parathyroid tumor and the initiation of ostitis fibrosa in human patients. Subsequently HansoN ${ }^{23,24)}$ and Collip ${ }^{12)}$ succeeded in extracting parathormone. Now the relationship between the bone and the parathyroid has become further clarified. On the other hand, BergStRAND ${ }^{5)}$ reported that about $20 \%$ of the patients with chronic glomerulonephritis might be accompanied by hyperplasia of the parathyroid. Since then, attention has been paid to the interrelation between the kidney and the parathyroid, which has been explained to be the renal hyperparathyroidism by PAPPENHEIMier and WILLENS ${ }^{42}$, and Gilmour and Martin ${ }^{19}$. Later, Ginzler and Jaffe ${ }^{20)}$ examined the bone and parathyroid of patients with chronic nephritis and pointed out osteodystrophia fibrosa and hyperplasia of the principal cells in the parathyroid as common lesions. EGER ${ }^{16}$ also reported that contracted kidney of the rat experimentally induced by uranium nitrate administration caused the enlargement of the parathyroid and osteodystrophia fibrosa successively. Thus, the problem concerning the osteorenal syndrome has now begun to be analyzed.

In his studies on the osteorenal syndrome in dogs, HARE ${ }^{25)}$ perceived, in 1933, simple epithelial hyperplasia in the parathyroid and ostitis fibrosa in the cranial bone, rib, and femur in about a half of 23 dogs with chronic interstitial nephritis, and stated that any interrelations among these lesions were unknown. After that, EIchHolz and OJEMANN ${ }^{17}$ ) similar lesions observed in their first cases manifesting the osteorenal syndrome. Up to now, this syndrome has been studied by Platt $^{45,46)}$, Broder ${ }^{8)}$, Nielsen and MaSherry ${ }^{37)}$, TrevinO ${ }^{53)}$, KRETZSCHMAR ${ }^{29)}, \mathrm{K}_{\text {ROOK }}{ }^{30)}$, and DÄMMERICri ${ }^{13)}$.

These authors agreed that in the pathogenesis of this syndrome, the primary lesion might be chronic interstitial nephritis or chronic glomerulonephritis, which caused renal hyperparathyroidism and then lesions in the bone. Especially, $\mathrm{K}_{\mathrm{ROOK}}{ }^{3 n}$ discussed the difference between primary hyperparathyroidism and renal hyperparathyroidism ${ }^{9}$. DAMmERICH ${ }^{13)}$ chiefly analyzed cytological changes of the parathyroid in detail. On the contrary, GratzL ${ }^{21}$ doubted the possibility that the parathyroid might be associated with the changes in the kidney and bone, although he agreed that canine nephritis could induce changes in the bcne. Moreover, Roos ${ }^{48)}$ stressed that not only renal hyperparathyroidism but also such exogenic factors as an error in feeding should be responsible for all bone lesions of dogs accompanied by lesions of the kidney, parathyroid, and bone. PALlaske ${ }^{40,41)}$ also stated a negative opinion as to the dependence of the bone lesions on the renal changes. Thus, there are still a number of unsolved problems concerning the osteorenal syndrome.

The papers cited above are mostly case reports and lack systematic analysis. Therefore

Jap. J. vet. Sci. 28, $217 \sim 228$ (1966) 
it is dangerous to refer to the mechanism of pathogenesis of the osteorenal syndrome only from the review of these papers. It is urged to investigate the basis of its causality.

So far as nephritis, especially interstitial nephritis, is concerned, dogs show an obviously high morbidity, as compared with the other domestic animals. This has been demonstrated by MaNider ${ }^{35)}$, VöGeLE ${ }^{54)}$, and MonLux ${ }^{36)}$ statistically. For this reason, the present author considered that the dog might be the best subject to be used for research on the osteorenal syndrome. It is natural that the study on this syndrome should be done not only through morphological observation but also by the examination: of the function. So the author tried at first to perform chiefly histopathological studies by observing necropsied cases of dogs, and to analyze this syndrome critically by adding more or less clinico-pathological discussion. The present paper deals with the outline of the results obtained, including the development mechanism of the osteorenal syndrome: and other interesting phenomena in the dog.

\section{MATERIALS AND METHODS}

The experimental materials used were composed of 38 dogs subjected to autopsy at: the Department of Comparative Pathology, Faculty of Veterinary Medicine, Hokkaido. University, Sapporo, Hokkaido. Specimens of general organs, including the kidney, parathyroid, and bone, collected from these dogs were all fixed in $10 \%$ formalin solution or Carnoy's fluid, embedded in paraffin (except for bone specimens which were embedded in celloidin), and stained with hematoxylin and eosin.

At first, the experimental materials were divided into two groups, one from which the parathyroid was taken out and the other which remained intact. The first group consisted of 26 dogs (11 males and 15 females), which were examined for the kidney, parathyroid, and bone. The second group was composed of 4 dogs (one male and 3 females), which were examined for the kidney and bone (Table 1). The bone materials.

Table 1. Data on Materials Examined

\begin{tabular}{cc|c|c|c}
\hline Sex & \multicolumn{4}{c}{ Groups of materials } \\
\cline { 2 - 5 } & $\begin{array}{c}\text { Cases with kidney, } \\
\text { parathyroid and } \\
\text { bone examined }\end{array}$ & $\begin{array}{c}\text { Cases with kidney } \\
\text { and bone examined }\end{array}$ & $\begin{array}{c}\text { Cases with kidney } \\
\text { and parathyroid } \\
\text { examined }\end{array}$ & $\begin{array}{c}\text { Cases with kidney } \\
\text { examined }\end{array}$ \\
\hline Male & $11^{*}$ & 1 & 3 & 204 \\
Female & 15 & 3 & 5 & 171 \\
\hline Total & 26 & 4 & 8 & 375 \\
\hline
\end{tabular}

* No. of cases.

used were of 7 kinds, including a cross section of the frontal and mandibular bone, a cross and longitudinal section of the rib and femoral bone, and a longitudinal section of the rib with costal cartilage. Specimens were collected also from the sacrum, tibia, and humerus when necessary. All the bone materials were decalcified electrically and embedded in celloidin.

Meanwhile, a third group was established. It consisted of 8 dogs $(3$ males and 5 females), which were examined for the kidney and parathyroid, but not for the bone. In addition, a fourth group was set up with 375 dogs (204 males and 171 females), from which kidney tissue was randomly collected and used for the examination. 


\section{RESULTS}

1. Case of kidney, parathyroid, and bone examined

The histological changes observed in the kidney, parathyroid, and bone of 26 autopsied dogs are summarized in Table 2. Of the renal changes, interstitial nephritis was the most important. Seven cases of the subacute type and 11 cases of chronic type were found. Of the parathyroid changes, hypertrophy and hyperplasia of the parenchymal cells were shown in 8 and 13 cases, respectively. Of the bone changes, initial lesions (focal loosening) were present in a majority of the cases. They were desolation changes of the compact substance and followed by the small-sized hole formation of the canal or non-canal system. In some cases, there were osteoclast in small-sized holes.

The hyperplastic changes in the lesions, however, were slight as compared with the above-described desolation changes. The inner arrangement of the osteoblast and

Table 2. Histopathological Findings in Cases with Kidney, Parathyroid and Bone Examined

\begin{tabular}{|c|c|c|c|c|c|c|c|}
\hline \multirow[b]{2}{*}{$\begin{array}{l}\text { Case } \\
\text { No. }\end{array}$} & \multirow[b]{2}{*}{$\begin{array}{l}\text { Necropsy } \\
\text { No. }\end{array}$} & \multirow[b]{2}{*}{ Breed } & \multirow[b]{2}{*}{ Age* } & \multirow[b]{2}{*}{ Sex } & \multicolumn{3}{|c|}{ Histo pathological findings } \\
\hline & & & & & $\begin{array}{l}\text { Interstitial } \\
\text { nephritis }\end{array}$ & $\begin{array}{l}\text { Changes of } \\
\text { parenchymal cells } \\
\text { of parathyroid }\end{array}$ & $\begin{array}{l}\text { Desolation } \\
\text { changes } \\
\text { of bone }\end{array}$ \\
\hline 1 & $\operatorname{Pr} 3798$ & Spitz & $7 M$ & Male & Subacute & Hypertrophy & Small-sized holes \\
\hline 2 & E 2583 & Ainuken & " & $\prime \prime$ & Chronic & $\begin{array}{l}\text { Hypertrophy and } \\
\text { hyperplasia }\end{array}$ & " \\
\hline 3 & $\operatorname{Pr} 3835$ & Mongrel & $2 Y$ & $\prime \prime$ & Subacute & $\prime \prime$ & $\prime \prime$ \\
\hline 4 & $\operatorname{Pr} 3768$ & Shepherd & $\prime \prime$ & $\prime \prime$ & $\prime \prime$ & $\prime \prime$ & $\prime \prime$ \\
\hline 5 & $\operatorname{Pr} 3791$ & Mongrel & $10 Y$ & $\prime \prime$ & 11 & " & $\prime \prime$ \\
\hline .6 & $\operatorname{Pr} 3874$ & "I & "l & $\prime \prime$ & Chronic & " & $\prime \prime$ \\
\hline 7 & $\operatorname{Pr} 3862$ & "I & $16 Y$ & $\prime \prime$ & "I & No change & $\prime \prime$ \\
\hline 8 & E 2980 & Spitz & $7 M$ & Female & $\prime \prime$ & $\prime \prime$ & 11 \\
\hline 9 & E 2995 & Setter & $13 M$ & "l & " & $\begin{array}{l}\text { Hypertrophy and } \\
\text { hyperplasia }\end{array}$ & $\prime \prime$ \\
\hline 10 & $\operatorname{Pr} 3832$ & Shepherd & $15 Y$ & $\prime \prime$ & Subacute & "I & $\prime \prime$ \\
\hline 11 & $\operatorname{Pr} 3922$ & Ainuken & $2 Y$ & $\prime \prime$ & Chronic & $\prime \prime$ & $\prime \prime$ \\
\hline 12 & $\operatorname{Pr} 3778$ & Spitz & $3 Y$ & $\prime \prime$ & Subacute & $\prime \prime$ & $\prime \prime$ \\
\hline 13 & $\operatorname{Pr} 3834$ & $\prime \prime$ & $4 Y$ & $\prime \prime$ & " & Hypertrophy & $\prime \prime$ \\
\hline 14 & $\operatorname{Pr} 3775$ & Shepherd & $6 Y$ & $\prime \prime$ & Chronic & $\begin{array}{l}\text { Hypertrophy and } \\
\text { hyperplasia }\end{array}$ & $\prime \prime$ \\
\hline 35 & $\operatorname{Pr} 3729$ & $\prime \prime$ & $7 Y$ & $\prime \prime$ & $\prime \prime$ & "I & $\prime \prime$ \\
\hline 16 & $\operatorname{Pr} 3737$ & $\begin{array}{l}\text { Wire haired } \\
\text { Fox Terrier }\end{array}$ & $\prime \prime$ & 11 & $\prime \prime$ & $\prime \prime$ & $\prime \prime$ \\
\hline 17 & $\operatorname{Pr} 3784$ & Shepherd & $9 Y$ & $\prime \prime$ & 11 & Hypertrophy & $\prime \prime$ \\
\hline 18 & $\operatorname{Pr} 3846$ & Mongrel & $13 Y$ & $\prime \prime$ & "' & " & $" \prime$ \\
\hline 19 & $\operatorname{Pr} 3821$ & Spitz & $2 \mathrm{M}$ & Male & No change & $\begin{array}{l}\text { Hypertrophy and } \\
\text { hyperplasia }\end{array}$ & $\prime \prime$ \\
\hline 20 & $\operatorname{Pr} 3801$ & Tosaken & $7 M$ & $\prime \prime$ & Nephrosis & No change & $\prime \prime$ \\
\hline 21 & $\operatorname{Pr} 3790$ & Ainuken & $13 M$ & "' & No change & Hypertrophy & $\prime \prime$ \\
\hline 22 & $\operatorname{Pr} 3793$ & Mongrel & $2 Y$ & Female & Nephrosis & $\begin{array}{l}\text { Hyperfrophy and } \\
\text { hyperplasia }\end{array}$ & $\prime \prime$ \\
\hline 23 & E 2586 & Spitz & $5 \mathrm{M}$ & " & $\begin{array}{l}\text { Calcium } \\
\text { deposition }\end{array}$ & No change & $\prime \prime$ \\
\hline 24 & $\operatorname{Pr} 3847$ & Ainuken & $\prime \prime$ & $\prime \prime$ & No change & Hypertrophy & "I \\
\hline 25 & $\operatorname{Pr} 3837$ & Collie & IY & $\prime \prime$ & $\stackrel{\prime \prime}{\text { Plasma-cell }}$ & $\begin{array}{l}\text { Hyperfrophy and } \\
\text { hyperplasia }\end{array}$ & No change \\
\hline 26 & $\operatorname{Pr} 3807$ & Boxer & $2 Y$ & $\prime \prime$ & $\begin{array}{l}\text { accumulation } \\
\text { in interstitium }\end{array}$ & $\prime \prime$ & Small-sized holes \\
\hline
\end{tabular}

* $M=$ months, $Y=$ year(s). 
apposition of the osteoid tissue were pointed out only along the margin of some of visible small-sized holes by the magnifier. It is obvious that these bone changes were due to osteodystrophia fibrosa, which was observed in 25 cases out of 26.

In as many as 16 cases out of 26, all the above-mentioned changes occurred in the kidney, parathyroid, and bone. In the remaining 10 cases, changes were distributed as follows: a cases of both bone and parathyroid changes with nephrosis, 2 cases without renal changes, 3 cases without parathyroid changes, 2 cases of bone changes alone, a case of parathyroidal changes alone, and a cases of nephrosis and bone changes.

2. Cases of kidney and bone examined

As shown in Table 3, both chronic interstitial nephritis and osteodystrophia fibrosa were recognized in 2 out of 4 cases examined.

The remaining cases had bone changes, but no renal changes.

Table 3. Histopathological Findings in Cases with Kidney and Bone Examined

\begin{tabular}{c|c|c|c|c|c|c|} 
& & & & \multicolumn{2}{|c|}{ Histopathological findings } \\
\hline Case No. & Necropsy No. & Breed & Age & Sex & $\begin{array}{c}\text { Interstitial } \\
\text { nephritis }\end{array}$ & $\begin{array}{c}\text { Desolation changes } \\
\text { of bone }\end{array}$ \\
\hline 27 & $\operatorname{Pr} 3748$ & Shepherd & $2 Y$ & Male & Chronic & Small-sized holes \\
28 & E 2974 & $\prime \prime$ & $6 Y$ & Female & $\prime \prime$ & $\prime \prime$ \\
29 & $\operatorname{Pr} 3803$ & Ainuken & $3 M$ & $\prime \prime$ & Congestion & $\prime \prime$ \\
30 & E 2963 & Shepherd & $7 Y$ & $\prime \prime$ & No change & $\prime \prime$
\end{tabular}

* See Table 2.

3. Cases of kidney and parathyroid examined

As shown in Table 4, 5 out of 8 cases examined in the group exhibited both interstitial nephritis and hypertropy or hyperplasia of parenchymal cells of the parathyroid. The remaining three cases showed parathyroidal changes, but not renal ones.

Table 4. Histopathological Findings in Cases with Kidney and Parathyroid Examined

\begin{tabular}{|c|c|c|c|c|c|c|}
\hline \multirow[b]{2}{*}{ Case No. } & \multirow[b]{2}{*}{ Necropsy No. } & \multirow[b]{2}{*}{ Breed } & \multirow{2}{*}{ Age* } & \multirow{2}{*}{ Sex } & \multicolumn{2}{|c|}{ Histopathological findings } \\
\hline & & & & & $\begin{array}{l}\text { Interstitial } \\
\text { nephritis }\end{array}$ & $\begin{array}{l}\text { Changes in Parenchymal } \\
\text { cells of parathyroid }\end{array}$ \\
\hline 31 & E 2364 & Mongrel & $2 Y$ & Male & Subacute & Hypertrophy and \\
\hline 32 & E 2207 & $\prime \prime$ & $4 Y$ & $" \prime$ & $\begin{array}{l}\text { Contracted } \\
\text { kidney }\end{array}$ & 11 \\
\hline 33 & $\operatorname{Pr} 3675$ & Setter & $5 Y$ & $\prime \prime$ & Chronic & $\prime \prime$ \\
\hline 34 & $\operatorname{Pr} 3875$ & Spaniel & $1 Y$ & Female & $\prime \prime$ & Hypertrophy \\
\hline 35 & E 2700 & Mongrel & $19 Y$ & $\prime \prime$ & Subacute & $\begin{array}{l}\text { Hypertrophy and } \\
\text { hyperplasia }\end{array}$ \\
\hline 36 & $\operatorname{Pr} 3849$ & Collie & $5 \mathrm{M}$ & $\prime \prime$ & No change & Hypertrophy \\
\hline 37 & $\operatorname{Pr} 3870$ & $\prime \prime$ & $6 M$ & $\prime \prime$ & $\prime \prime$ & 11 \\
\hline 38 & $\operatorname{Pr} 3806$ & Shepherd & $6 Y$ & $\prime \prime$ & $\prime \prime$ & $\begin{array}{l}\text { Hypertrophy and } \\
\text { hyperplasia }\end{array}$ \\
\hline
\end{tabular}

* See Table 2.

4. Cases of kidney examined

In order to investigate the influence, if any, of the changes found in canine cases. at autopsy, 375 kidneys were collected randomly and studied histopathologically. Renal changes were observed in 175 cases $(46.7 \%)$ of the 375 . Of them, interstitial nephritis 
Table 5. Relationship between Lesions and Age in 175 Cases with Renal Lesions

\begin{tabular}{|c|c|c|c|c|c|c|c|c|c|c|}
\hline Renal lesions & \multicolumn{9}{|c|}{ Age (in years) } & Total \\
\hline Nephrosis & 11 & 2 & & & & & & & & 13 \\
\hline \multicolumn{11}{|l|}{ Glomerulonephritis } \\
\hline Acute & 7 & 1 & 1 & & & & & & & 9 \\
\hline Subacute & 1 & & & & 1 & & & & & 2 \\
\hline Chronic & & & & 2 & 2 & & & & & 4 \\
\hline \multicolumn{11}{|l|}{ Focal interstitial nephritis } \\
\hline Subacute & 24 & 7 & 3 & i & 2 & 2 & & 1 & 2 & 42 \\
\hline Chronic & 2 & 5 & 2 & 2 & 1 & & 1 & 1 & 3 & 17 \\
\hline \multicolumn{11}{|l|}{ Diffuse interstitial nephritis } \\
\hline Subacute & 8 & 4 & 5 & 1 & 1 & & 1 & 1 & & 21 \\
\hline Chronic & 1 & 6 & 1 & 3 & 3 & & 2 & 1 & 1 & 18 \\
\hline Contracted kidney & & & 1 & & & & & 1 & 1 & 3 \\
\hline Small foci of accumulated cells & 11 & 2 & 1 & 1 & 2 & & & & & 17 \\
\hline Granuloma & 6 & 1 & & & & & 1 & 1 & & 9 \\
\hline Infarction & 2 & & & & 1 & & 1 & 1 & & 5 \\
\hline Lymphadenoma & 1 & & & & & & & & & 1 \\
\hline Pyelitis & 3 & 2 & 1 & & & & & & & 6 \\
\hline Metastatic sarcoma & & & & & & & & & 1 & 1 \\
\hline Calcareous deposition & 5 & & & & 1 & 1 & & & & 7 \\
\hline Total & 82 & 30 & 15 & 10 & 14 & 3 & 6 & 7 & 8 & 175 \\
\hline
\end{tabular}

was recognized in 101 cases $(57.5 \%)$ of the 175 . The other renal changes were glomerulonephritis $(8.5 \%)$, nephrosis $(7.4 \%)$, granuloma $(5.1 \%)$, small lesions of cell accumulation, infarct, pyelitis, calcareous deposition, etc (Table 5). As a result, the importance of interstitial nephritis was proved. In the second place, the morbidity of interstitial nephritis was classified according to the age, as shown in Table 6.

It is noteworthy that the morbidity became high at ages older than 2 years, and that chronic interstitial nephritis increased in morbidity in accordance with the advance in age. On the basis of the findings obtained from the present research, interstitial nephritis could be regarded as the representative one of the canine renal changes observed.

\section{DISCUSSION}

1. Changes of the kidney

Statistically, BLOOM ${ }^{6}$, VöGELE ${ }^{54)}$, and MonLux $^{36)}$ already demonstrated that the morbidity of nephritis is very high among dogs. It has been said that interstitial

Table 6. Incidental Frequency of Interstitial Nephritis in Renal Lesions

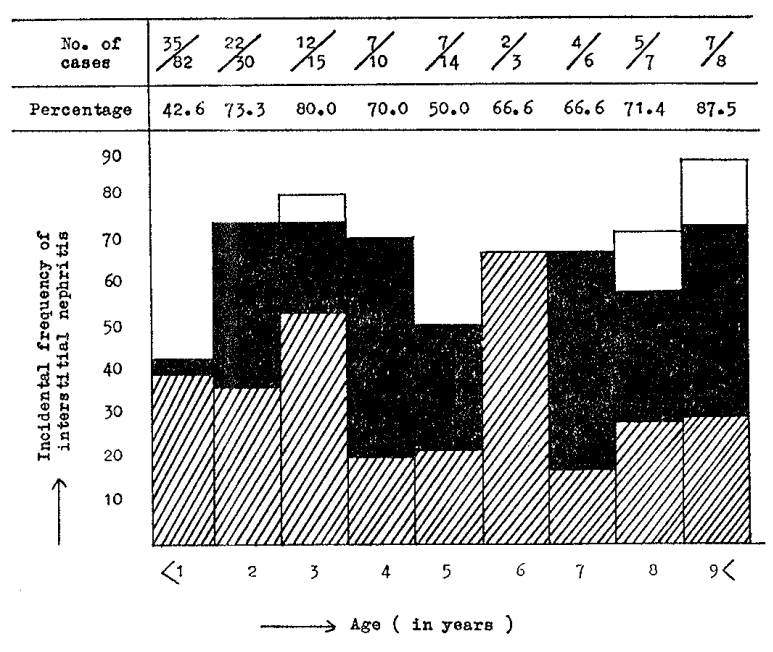

VIIIS Subacute form. Chronic form. Contracted kidney. 
nephritis is a principal lesion in the kidney.

Many reports dealing with the canine renal changes, however, lack consideration on the relationship between these changes and age.

Consequently, there has been no clear explanation on the pathogenesis of this type of nephritis in the dog. The author examined the canine renal lesions of 175 dogs, taking their ages into consideration. It must be borne in mind in the observation of these dogs that the first group was composed of dogs less than 12 months old and the second grous of dogs more than 13 months old. In both groups, interstitial nephritis was the main renal changes. It occurred in $42.6 \%$ (35 of 82 cases) and $70.9 \%$ (66 of 93 cases) of the renal lesions in the first and the second group, respectively. As to interstitial lesions of the kidney, the subacute form with focal lesions was mainly shown in the first group. In the second group, however, there were considerable differences in the form of nephritis due to age, and the chronic form with diffusive lesions increased in accordance with the advance in age. This state of occurrence of nephritic lesions agrees with the results obtained by OphüLs ${ }^{38}$, WIRth and Pommer ${ }^{57,58)}$, and Stevens et al..50), who found from their observations on experimentally induced nephritis that in dogs less than 12 months of age, interstitial lesions are not yet able to develop into chronic and diffusive ones due to the time limitation for progress of nephritis. In the 101 cases of interstitial nephritis which the author had obtained for the present investigation, histological examination revealed the occurrence of many kinds of interstitial lesions, from the subacute to the chronic form, and contracted kidney.

In addition to the cortico-medullary junction in the kidney, as reported by MCINTYRE ${ }^{34)}$, Monlux ${ }^{36)}$, and YAmamoto ${ }^{62}$, perivascular parts in the deep layer of the renal cortex are pointed out as sites of frequent occurrence of these initial interstitial lesions. Generally speaking, the initial lesions of the interstitium expand from the above-mentioned parts to the superficial layers in the renal cortex or the upper layers of the renal medulla, being either funicular or dendritic in shape.

Judging from the development of renal lesions, many cases of canine interstitial nephritis, the author would like to stress, are caused by hematogenous phlogogen.

The vascular changes of interstitial nephritis remained as secondary changes from renal interstitial lesions and were in good agreement with the result reported by HARE ${ }^{25)}$, MaIntyre ${ }^{34)}$, Platt ${ }^{44)}$, and Haga et al. ${ }^{22)}$ Primary contracted kidney, which has been reported by $\mathrm{INNES}^{26)}$, was not observed.

One changes characteristic of canine interstitial nephritis is calcareous deposition, as pointed out by MaFadyean ${ }^{33)}$, Pallaske ${ }^{39}$, Kretzsahmar ${ }^{20)}$, Nielsen ${ }^{37}$, , Krook ${ }^{30}$, and DÄMmERIGH ${ }^{13}$. In the present investigation, calcareous deposition was observed in Bowman's capsules, glomeruli, renaltubules, collecting tubules, interstitial tissue, and the walls of arterioles. This phenomenon was especially frequent in the case of chronic nephritis. As the cause of the renal calcareous deposition, BLoom ${ }^{7}$ regarded the uremic condition.

TSCHERnIAK and Romanov ${ }^{52)}$ attributed, though not firmly, to a severe disturbance of calcium metabolism. The present author, however, think that these changes resulted from an excretory disturbance of calcium and phosphorus induced by renal damage, since calcareous deposition occurred not only in the kidney, but also in many other organs accompanying metastatic calcification.

2. Changes of the parathyroid

Some investigators, including LIEGEoIs and Deribaux ${ }^{32)}$, reported that chronic nephritis in the dog brought about the hyperfunction of the parathyroid. Examining 34 cases, the present author also observed histopathological changes of parenchymal cells 
of the parathyroid in 30 cases.

The histological changes of these cases were classified into the following two group: (a) hypertrophy (22 cases) and (b) hypertrophy with hyperplasia (8 cases). The latter :group included hypertrophy and hyperplasia of chief cells with light-stained cytoplasm and occurrence of water clear cell. In short, one-dimensional hyperfunctional changes alternating from a dark to a light chief cell were pointed out.

The changes observed by the present author seemed to be in accordance with the renal hyperparathyroidism reported by other authors. Then examination was performed to elucidate their relationship with renal lesions. As a result, of 8 cases of hypertrophy of chief cells in the parathyroid, 4 cases were involved in interstitial nephritis. Of 22 cases of hypertrophy and hyperplasia in the parathyroid, 18 cases had, renal lesions. Of the 18 cases, only one showed nephrosis and an other interstitial nephritis. Of those who made studies on renal hyperparathyroidism in the dog, HARE ${ }^{25)}$, BrodeY ${ }^{8}$, NIELSEN and McSherry ${ }^{37}$, and Trevino ${ }^{53)}$ checked hyperplasia of chief cells, DÄMmerich ${ }^{13)}$ pointed out hypertrophy and hyperplasia of chief cells, KRETSGHMAR ${ }^{29}$ noticed hypertrophy of water clear cells, and PLATT ${ }^{45)}$ observed hyperplasia of chief cells in addition to the compact arrangement of the parathyroid parenchymal cells exhibiting a hyperfunctional state of the organ.

The findings obtained by the present author are in good agreement with the above -mentioned authors. Therefore, they seem to offer a strongly positive evidence for the presence of a close relationship between the renal lesions and hyperparathyroidism. More precise examination, however, might be necessary to confirm such relationship completely. In the present author's own observation, there were 8 cases where lesions were found in the parathyroid, but not in the kidney.

This result needs to be explained. In the previous reports, hyperparathyroidism was discussed exclusively in cases where this changes was combined with renal changes. No attempt has been made to examine such cases lacking renal changes as the present author studied herin. It is, however, YAmaGrwa et al. ${ }^{60,61}$ ) who alone described a noteworthy finding that osteodystrophia fibrosa in the horse was accompanied by secondary hyperparathyroidism originated from bone lesions.

The present author also paid an attention to this point, considering that it is necessary to examine bone changes in the 8 cases accompanied by parathyroidal changes but lacking renal lesions.

3. Changes of the bone

As already mentioned, the present author thought it indispensable to analyze histological changes of the bone in autopsied cases after clarification of the relationship between nephritis and hyperparathyroidism. The kidney, parathyroid, and bone were examined in 26 cases and the kidney and bone in 4 cases. Of the 30 cases examined for bone tissue, 29 cases were found to be accompanied by many kinds of pathological changes. The present author thought it desirable to classify the bone changes into two kinds, desolation and hyperplasia according to the classification of YAmAGIWA et al. ${ }^{59)}$ In the desolation changes are included various stages of lesions, such as the initial lesions in the compact substance observed by YAMAGIWA et al. ${ }^{59)}$ formation of small-sized holes related to the bone canal or non-canal system, and the apparence of osteoclasts in the small-sized holes. In the hyperplastic changes are included the arrangement of osteoblastic layers and hyperplasia of osteoid tissue in some parts of the inner walls of smallsized holes visible by the aid of a magnifier. The hyperplastic changes, however, were generally much slighter than the desolation changes, so far as the bone was concerned. It is considered that the general bone changes are those in which "Abbau" is more 
predominant than "Anbau". Therefore, the bone changes may be thought to belong: to the "hypostotisch-porotische Form" of osteodystrophia fibrosa according to Ghristeller's ${ }^{10,11)}$ classification. Since lesions were commonly observed in all the bones studied, including the frontal bone, rib, mandibula, and femur, bone lesions might be distributed generally in the bone tissue.

If so, the disease in question might be called osteodystrophia fibrosa generalisata, just as reported by Roos ${ }^{48)}$, Arndt ${ }^{2)}$, Kovács ${ }^{28)}$, Stockmeyer ${ }^{51)}$, and others ${ }^{49,55)}$. Then, taking the bone changes into consideration in analyzing the relationship between the kidney and the parathyroid, the following three groups of lesions were recognized. Group A: Closely related lesions occurring commonly in the kidney, parathyroid, and bone (Case Nos. 1-6, 9-18, and 22); renal lesions following pathogenetically and bringing about parathyroidal and bone changes, i.e., the osteorenal syndrome. Group B: Lesions occurring. only in the parathyroid and bone (Case Nos. 19, 21, 24, and 26); bone changes brought about independently from renal ones and following hyperparathyroidism. Group C: Lesions occurring only in the parathyroid (Case No. 25); Judging on the pathognesis of the lesions is unknown.

According to the classification above, all the experimental materials used by the present author can be divided into the three group. Needless to say, the cases with lesions in the kidney and bone belong to Group A (Gase Nos. 27 and 28) and those with lesions only in bone of the two organs to Group B (Case Nos. 29 and 30). In the same fashion, the cases with lesions closely related to the kidney and parathyroid belong to Group A (Case Nos. 31-35). It was suspected that bone changes might have occurred in these cases. The cases with lesions in the parathyroid alone are desired to be classified into Group B or C (Case Nos. 36-38).

4. Osteorenal system

As mentioned above, the author referred in the present paper to nephritis, changes in the parathyroid and the bone, and made discussion on a number of cases examined in which an interrelationship might be positively present in the development of lesions among these three organs. The principal lesions in these organs were co-existing interstitial nephritis, hypertrophy and hyperplasia of the parathyroid, and osteodystrophia fibrosa, all of which are collectively called the osteorenal syndrome.

In a few cases reported of the osteorenal syndrome in the dog, the primary lesions of this syndrome were chronic interstitial nephritis, hyperphosphatemia, which had been induced by the nephritis, renal hyperparathyroidism, induced in succession, and osteodystrophia fibrosa occurring as a result. This is the mechanism of pathogenesis of the osteorenal syndrome.

Opposed to the above-mentioned opinion are PApPenhermer and W ILLens $^{42}$, Pappenheimer ${ }^{43)}$, Jaffe et al..27), Eger ${ }^{16)}$, Gratzl ${ }^{21)}$, Pallaske ${ }^{41)}$, and Ginzler and $\mathrm{JAFFE}^{20)}$. According to them, renal hyperparathyroidism is not so predominant as to induce bone changes and renal damage may directly give rise to acidosis, which become the direct cause of decalcification from the bone, independently from the presence of the parathyroid. It may be possible to consider the active participation of the parathyroid in the appearance of the osteorenal syndrome. In many of the cases which the author classified in to a group manifesting the osteorenal syndrome from a morphological point of view, there were changes related to the kidney, parathyroid, and bone. Moreover, the same opinion may be applicable to those cases in which changes were observed in the parathyroid and the kidney, but from which no bone materials were available, and to those cases in which changes were observed in the bone and kidney, but from which parathyroidal materials were not available. These two group of cases might be 
safely treated as belonging to the same category. In these cases, as few as 4 in number (Case Nos. 7, 8, 20, and 23), no parathyroidal abnormality was present, in spite of changes in the kidney and the bone. In this connection, the present author makes the following postulate as to the pathogenesis of bone lesions in the osteorenal syndrome: The metabolic or excretory disturbance originated from renal damage gives directly rise to bone changes without participation of the parathyroid. In making this postulate, the author has not taken other investigators' one-dimentional explanation into consideration. Only chronic nephritis has previously been pointed out as a renal lesion of the osteorenal syndrome in the dog.

From the present author's cases, new information seems to have been obtained that this syndrome appears in cases of subacute interstitial nephritis and nephrosis. On the other hand, as a remarkable finding in the present study, there were 4 cases in which changes occurred in the bone and the parathyroid, but not in the kidney. Bone changes in these cases must be ascribed to nutritional disorders due to exogenic causes, especially unnatural feeding, and hyperparathyroidism accompanied by what were considered to be rather secondary lesions from bone changes.

No pathological examination has been carried out as yet on hyperparathyroidism originated from such bone changes in the dog. This should be emphasized.

In short, the present author was able to demonstrate that hyperparathyroidism was induced either by renal damage or by bone changes.

As described above, the present author's discussion was focused on the interrelationship of lesions among the kidney, parathyroid, and bone.

As a result, he obtained a number of findings indicating that the osteorenal syndrome might actually be operative ultimately.

\section{SUMMARY}

Investigation was carried out to determine whether there were pathological changes (the so-called osteorenal syndrome) related to three organs, the kidney, parathoroid, and bone in the dog or not. As a result of histopathological studies, the following findings were obtained.

1. An evidence was obtained from 28 cases examined to show the occurrence of the osteorenal syndrome.

2. It is assumed that the initiation of the osteorenal syndrome depends on the combination of hyperparathyroidism and osteodystrophia fibrosa, which in general follow renal changes.

3. There were many cases in which the occurrence of bone lesions in the osteorenal syndrome was not only due to renal hyperparathyroidism but also closely related to changes in the kidney and bone, without any participation of the parathyroid.

In this respect, further examination seems to be necessary to know the pathogenesis. of the osteorenal syndrome.

4. It should be taken into consideration that the appearance of renal changes as primary lesions of the osteorenal syndrome is not limited to cases of chronic nephritis, but is extended to cases of subacute interstitial nephritis and nephrosis.

5. There were four cases which showed hyperparathyroidism and osteodystrophia fibrosa, but no renal changes.

These cases are of great interest. They were induced by nutritional disorders of the bone. These disorders may be comparable to the osteorenal syndrome in reference to the cause of lesional changes. 


\section{ACKNOWLEDGMENTS}

The author wishes to express this gratitude to Dr. S. YamagiwA, president, Obihiro Zootechnical university, for his kind direction and review of this manuscript. Thanks are also due to Professor Y. Fujimoto and Assistant Professor H. SAToH, of the Department of Comparative Pathology, Faculty of Veterinary Medicine, Hokkaido University, for many valuable suggestions.

\section{REFERENCES}

1) Albright, F., Baird, P. G., Cope, O. and Bloomberg, E. (1939): Amer. J. med. Sci., 187, $49 \sim 65$.

2) Arndt, T. M. (1926): Dtsch. tierärztl. Wschr., 34, 760 761.

3) Askanazy, M. (1926): Arb. path. Anat. Bakt. path.-anat. Inst. Tübingen, 4, 398 422.

4) Bensley, S. H. (1947): Anat. Rec., 98, 361 377.

5) Bergstrand, H. (1920): Acta. med. scand. 54, 345 388.

6) Bloom, F. (1937): J. Amer. vet. med. Ass., 92, 679 699.

7) Bloom, F. (1941): Cornell. Vet., 31, 266 288.

8) Brodey, R. S. (1954): J. Amer. vet. med. Ass., 124, 275 278.

9) Castleman, B.R. and Mallory, T. B. (1935): Amer. J. Path., 11, 1 72.

10) Ghristeller, E. (1923): Ergebn. allg. Path., 20, 1 184.

11) Christeller, E. (1926): Verh. dtsch. path. Ges., 21, $7 \sim 48$.

12) Collip, J. B. (1925): J. biol. Chem., 63, 395 438.

13) DÄmmerich, K. (1958): Zbl. Vet.-Med., 5, 742 768.

14) Davies, G.O. (1936): Vet. Rec., 48, 1399 1404.

15) Drake, J.G., Albright, F. and Castleman, B. (1937): J. clin. Invest., 16, 203 206.

16) Eger, W. (1940): Virchows Arch. path. Anat. 306, 183 192.

17) Eichholz, P. C. and Ojemann, J. G. (1941): Wien. tierärztl. Mschr., 28, $351 \sim 354$.

18) Fahr, Th. (1934): Henke-Lubarsch's Handbuch der Speziele Pathologischen Anatomie und Histologie, 2 Aufl., VI/2, p. 907, Berlin, Springer.

19) Gilmour, J.R. and Martin, W. J. (1937): J. Path. Bact., 17, 293 301.

20) Ginzler, A. M. and Jaffe, H. J. L. (1941): Amer. J. Path., 17, 293 301.

21) Gratzl, F. (1941): Wien. tieräzrtl. Mschr., 28, 225 234.

22) Haga, M., Fujimoto, Y. and Ono, T. (1953): Jap. J. vet. Sci., 15, 135 146 (in Japanese).

23) Hanson, A. M. (1923): Milit. Surg., 52, 280.

24) Hanson, A. M. (1924): Milit. Surg., 55, 701.

25) Hare, T. (1933): Proc. roy. Soc. Med., 27, 796 801.

26) InNes, J. R. M. (1930): Vet. Rec., 5, 698 702.

27) Jaffe, H. J. L., Bodansky, A. and Ghanuler, J. (1932): J. exp. Med., 56, 823 834.

28) Kovács, J. (1939): Arch. wiss, prakt. Tierheilk., 75-76, 150 154.

29) KretzschmaR, G. H. (1956): Tierärztl. Umsch., 11, 12 16.

30) Krook, L. (1957): Acta path. microbiol. scand., Suppl., 122, 9 81.

31) Leberman, P. R. (1940): Surg. Gynec. Obstet.( 70, 925 934.

32) Liegeors, F. and Derivaux, J. (1946): C. R. Soc. Biol. (Paris), 140, 1143 1145.

33) MCFadyean, J. (1929): J. comp. Path., 42, 58 71, 141 162 and 230 241.

34) McIntyre, W. I. M. and Montgomery, G. I. (1952): J. Path. Bact., 64, 145 160.

35) McNider, W. D. (1916): J. med. Res., 34, 177 230.

36) Monlux, A.W. (1953): Amer. J. vet. Res., 14, 425 439.

37) Nielsen, S.W. and MCSherry, B. J. (1954): J. Amer. vet. med. Ass., 124, 270 274.

38) Ophüls, W. (1908): J. med. Res., 18, 497 507.

39) Pallaske, G. (1934): Arch. wiss. prakt. Tierheilk., 67, 103 113.

40) Pallaske, G. (1934): Arch. wiss. prakt. Tierheilk., 67, 503 512.

41) Pallaske, G. (1935): Tierärztl. Rdsch., 41, 577 582.

42) Pappenheimer, A. M. and Willens, S. L. (1935): Amer. J. Path., 11, 73 91. 
43) Pappenheimer, A. M. (1936): J. exp. Med., 64, 965 980.

44) Platt, H. (1951): J. comp. Path., 61, 140 149.

45) Platt, H. (1951): J. comp. Path., 61, 188 196.

46) Platt, H. (1951): J. comp. Path., 61, 197 214.

47) Platt, H. (1952): J. Path. Bact., 64, 539 549.

48) Roos, R. (1956): Inaugural-Dissertation zur Erlangung der Doktorwürde, Giessen.

49) Schmey, P. M. (1915): Virohows Arch. path. Anat. 220, 52 62.

50) Stevens, S. G. E., Clank, J. J. and Seller, A. F. (1956): Amer. J. vet. Res., 17, 389 397.

51) Stockmeyer, W. (1931): Arch. wiss. prakt. Tierheilk. 62, 602 616.

52) Tscherniak, W. S. and Romanov, N. A. (1931): Arch. wiss. prakt. Tierheilk., 63, 436 458.

53) Trevino, G.S. (1955): Southwest. Vet., 8, 338 340.

54) Vögele, E. (1920): Inaugural-Dissertation zur Erlangung der Doktorwürde, Berlin [cited from Berl. Münch. tierärztl. Wschr., 39, 492 (1923)].

55) Weber, M. (1929): Beitr. path. Anat., 82, 383, 423 and 514 554.

56) Winternitz, M.C. and Quinby, W.G. (1917): J. Urol. (Baltimore), 1, 139 165.

57) Wirth, H. D. and Pommer, A. (1937): Wien. tierärztl. Mschr., 24, $97 \sim 104$.

58) Wrrth, H. D. and Pommer, A. (1937): Wien. tierärztl. Mschr., 24, 257 262.

59) Yamagiwa, S. and Satoh, H. (1957): Acta path. jap., 7, 85 93.

60) Yamagiwa, S., Satoh, H., Ito, H. and Inubushi, H. (1958): Jui Chikusan Shimpo, No. 245, 1385 $\sim 1388$ (in Japanese).

61) Yamagiwa, S., Satoh, H., Ito, H. and Inubushi, H. (1959): Jui Chikusan Shimpo, No. 246, 5〜 13 (in Japanese).

62) Yamamoto, S. (1940): Jap. J. vet. Sci., 2, 39 70 (in Japanese).

\title{
犬における骨腎系の病理学的研究
}

\author{
一条茂 \\ 率広育産大学
}

(昭和 41 年 5 月 10 日受付)

犬に扔ける腎，上皮小体および骨の病変の関連性 (骨腎系症候群)を知るため，腎・上皮小体・骨検索 例 26 例，腎・骨検索例 4 例，腎・上皮小体検索例 8 例および参考としての整検索例 375 例を加えた合 計 413 例について, 病理組織学的研究を行ない, 次 つ結果を得た。

1. 腎・上皮小体・骨検索例，腎・骨検索例抢上 び腎・上皮小体検索例の合計 38 例のうち，28例に 骨腎症候群を肯定すべき所見が認められた。

2. 骨腎症候群の発現は, 一般的には, 腎病変に 継発した上皮小体機能充進抢よび繊維性骨栄養障害 症の組合わせによると解される.

3. 本症侯群にお打る骨病変は，征来，一義的に 腎性上皮小体機能元進の結果招来されるとされてい る。しかし著者は，上皮体の介在性変化を認め得な いで，主しろ腎および骨の両病変の直接的関連性を
首肯される例にも遭遇した。

4. 以上の点加ら，骨腎症候群の病理発生につい ては、今後さらに検討の必要がある所以を知り得た。

5. 犬の骨筱症侯群における原発性腎病変として は，慢性間質性督炎または慢性糸球体腎炎などの終 末腎病変に限られるべきものではなく，巠急性間質 性腎炎, さらにはネフローゼなどの早期病変の場合 にまで，拡張されるべきものと解された。

6. 上皮小体変化として, 主細胞の淡明化と肥大. 増生および water clear cell の出現, ならびに腺胞 構造の不規剆化を示す実質細胞配列の異常などを含 めた上皮小体機能六進像が指摘された.

7. 骨病変は, 発端病巣に始まって, 管腔性ない し非管性の多中心性小孔形成におよふ Osteodystrophia fibrosa generalisata の像を呈していた.

8. 石灭転移は, 本症候群例較に比的頻発寸る所 
見であって，28 例中 10 例に警を始めとして，霄粘

膜，肺胞壁，胸膜，脾柱，気管支軟骨，子宦粘膜， 骨格筋々間動脈壁，心内膜，大動脈壁などに，その 世現安認得た。

この窔化は，算障䇺に多くを帅すべきものと思考 される。

9. 非简性の繊維性骨栄養障害症に，上皮小体の 増生性変化を伴った 4 例を得た。犬におけるこの例 に類した報告は，往来觜無である。このような例の

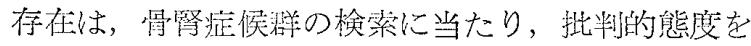
保持する必琶性走示唆するものと思われる。
10. 掔榆索例 375 例のうち, 病変が認められた ものは175 例の多数におよんだ、简病変の主体をな すものは間質性腎炎て，101例の高頻度に達した。

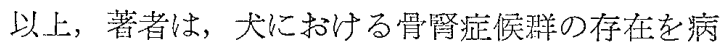
理組織学的に確認し， あわ女て従来の報告にみられ ない本症候群に属する而病变の種々相定系統的に解 明し，進んで本症倔群発病病理学説における一元的 解积に批判を加えた。また，简病変とは無関係に， 繊維性骨栄湌障害症および上皮小体機能京進像を呈 する例老得て，大の小皮小体機能吉進像の発現の一 元的でないこと学山明らかにした。

\section{EXPLANATION OF PLATES}

PLATE I

Fig. 1. Case No. 1. Subacute interstitial nephritis. Hematoxylin and eosin stain (H-E), $\times 130$

Fig. 2. Gase No. 1. Small-sized hole formation under periosteum of the rib. H-E, $\times 130$.

Fig. 3. Gase No. 1. Hypertrophy of parenchymal cells of the parathyroid. $\mathrm{H}-\mathrm{E}, \times 335$.

Fig. 4. Gase No. 4. Focal and subacute interstitial nephritis. H-E, $\times 130$.

Fig. 5. Case No. 4. Focal loosening (initial lesion) of the os antebrachii. H-E, $\times 335$.

Fig. 6. Case No. 4. Hypertrophy and hyperplasia of parenchymal cells of the parathyroid. H-E, $\times 335$.

\section{PLATE II}

Fig. 7. Case No. 6. Ghronic interstitial nephritis. H-E, $\times 130$.

Fig. 8. Case No. 6. Highly developed small-sized hole formation of the mandibula. H-E, $\times 130$.

Fig. 9. C'ase No. 6. Hypertrophy and hyperplasia of parenchymal cells of the parathyroid. H-E, $\times 335$.

Fig. 10. Case No. 7. Subacute interstitial nephritis. H-E, $\times 130$.

Fig. 11. Case No. 7. Small-sized hole formation of the femur. H-E, $\times 130$.

Fig. 12. Case No. 7. Normal parathyroid. H-E, $\times 130$.

\section{PLATE III}

Fig. 13. Case No. 9. Chronic interstitial nephritis. H-E, $\times 130$.

Fig. 14. Case No. 9. Small-sized hole formation of the mandibula. H-E, $\times 130$.

Fig. 15. Case No. 9. Hypertrophy and hyperplasia of parenchymal cells of the parathyroid. Increase is seen in number of chief cells with light-stained cytoplasm rich in volume. $\mathrm{H}-\mathrm{E}, \times 335$.

Fig. 16. Case No. 10. Subacute interstitial nephritis. H-E, $\times 130$.

Fig. 17. Case No. 10. Focal loosening (initial lesion) under periosteum of the mandibula. H-E, $\times 335$.

Fig. 18. Case No. 10. Hypertrophy and hyperplasia of parenchymal cells of the parathyroid. H-E, $\times 335$.

\section{PLATE IV}

Fig. 19. Case No. 15. Chronic interstitial nephritis. H-E, $\times 130$.

Fig. 20. Case No. 15. Focal loosening (initial lesion) of the frontal bone. H-E, $\times 335$.

Fig. 21. Case No. 15. Hypertrophy and hyperplasia of parenchymal cells of the parenthyroid. Irregular and compact arrangement of chief cells is seen. $\mathrm{H}-\mathrm{E}, \times 130$.

Fig. 22. Case No. 22. Nephrosis. H-E, $\times 130$.

Fig. 23. Case No. 22. Small-sized hole formation of the mandibula. H-E, $\times 130$.

Fig. 24. Case No. 22. Hypertrophy and hyperplasia of parenchymal cells of the parathyroid. Increase is seen in number of chief cells with light-stained cytoplasm. Chief cells are irregular arranged. $\mathrm{H}-\mathrm{E}, \times 335$. 


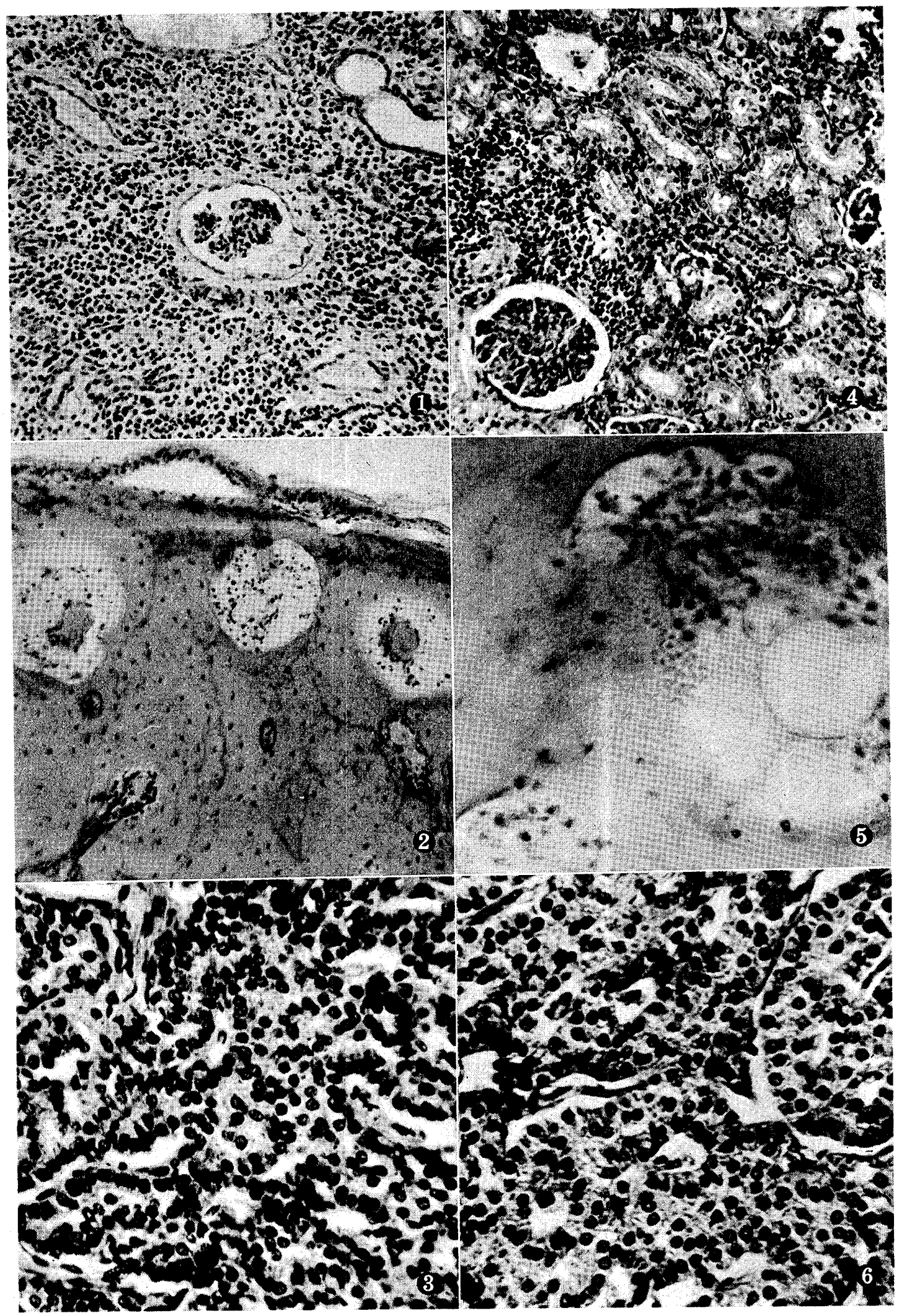




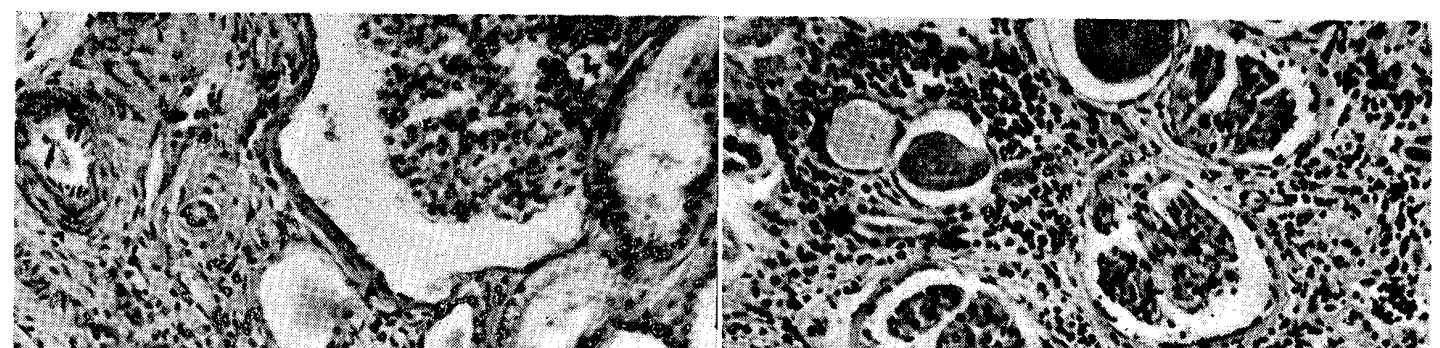

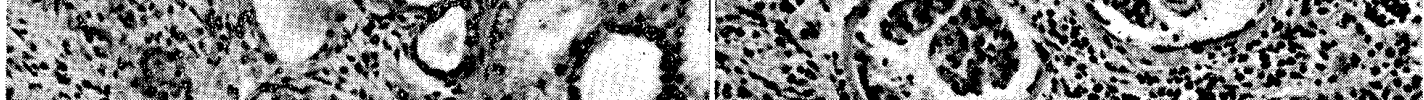

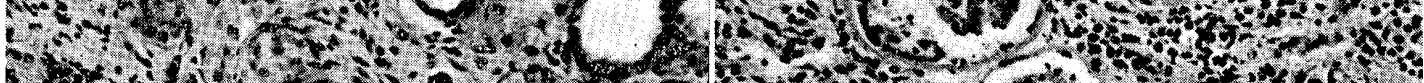

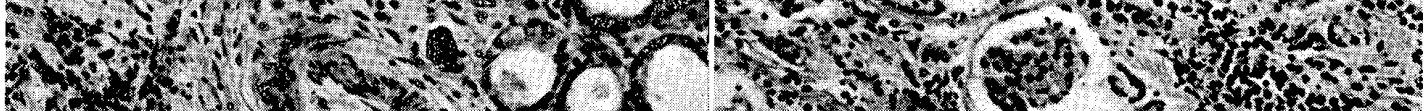

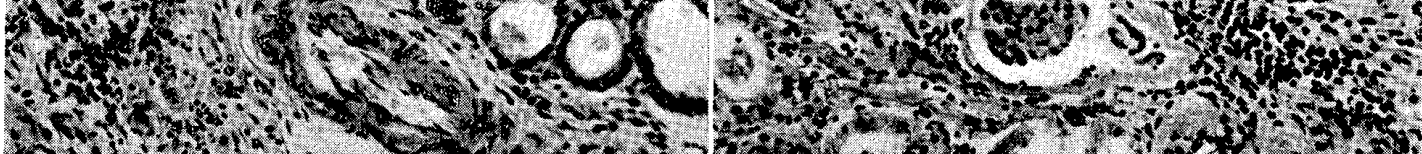

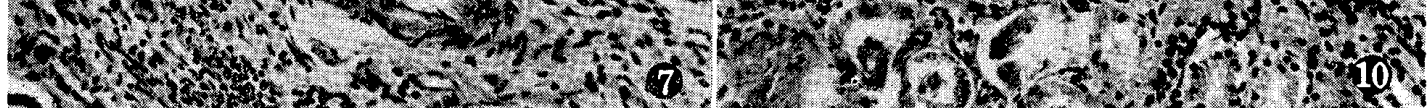

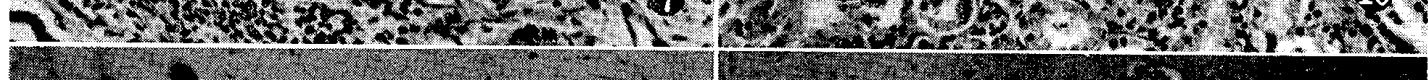

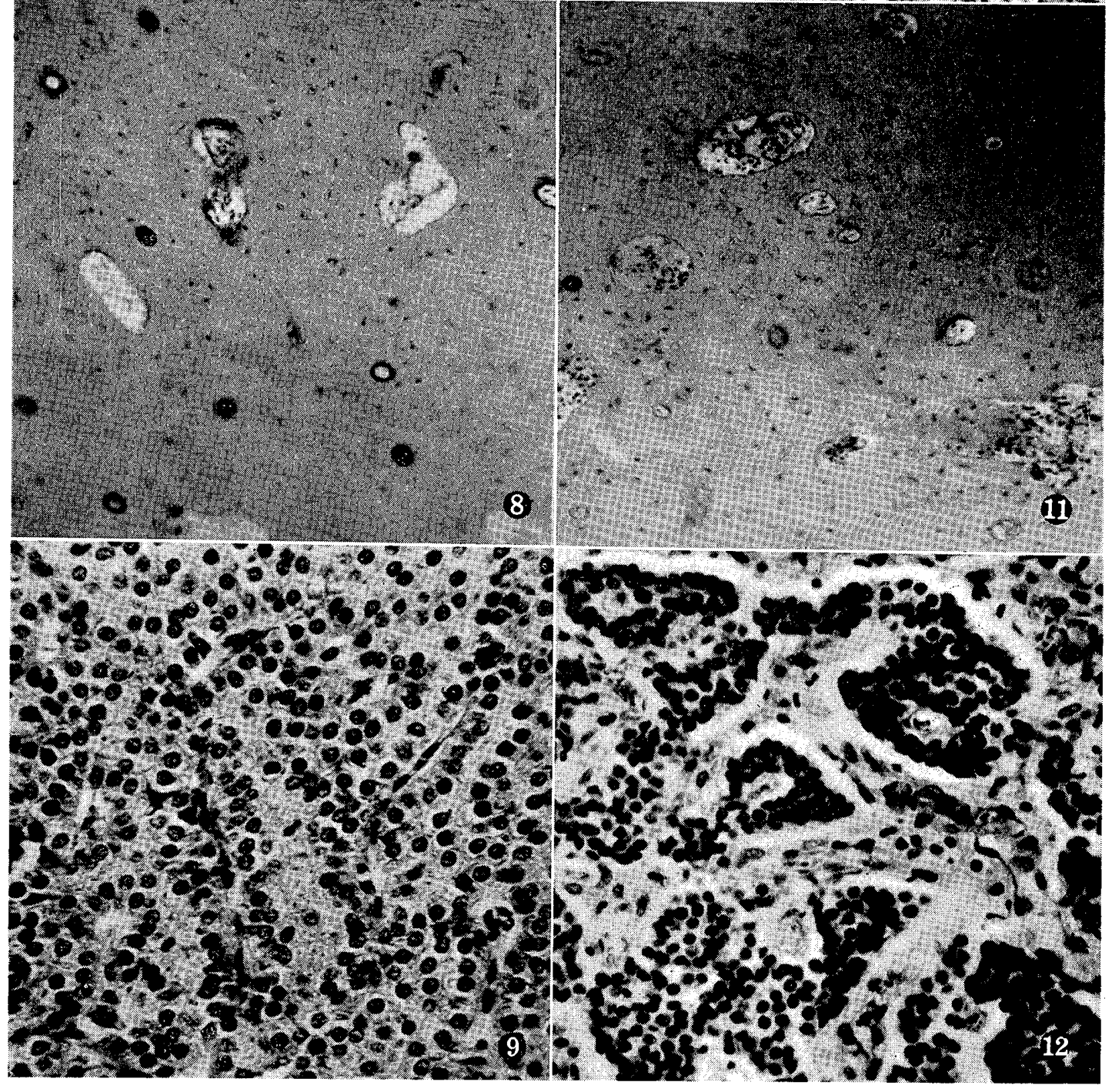




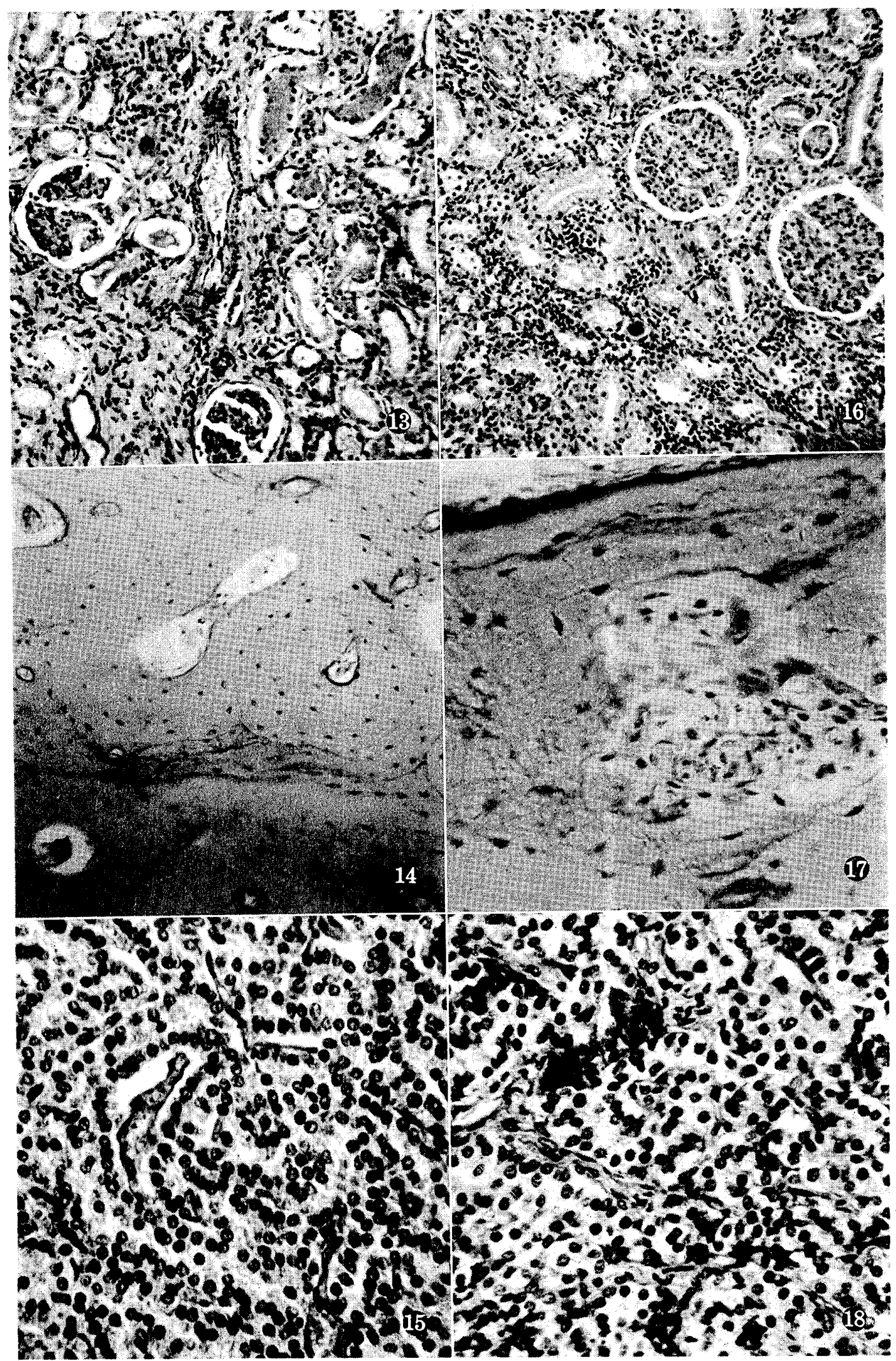




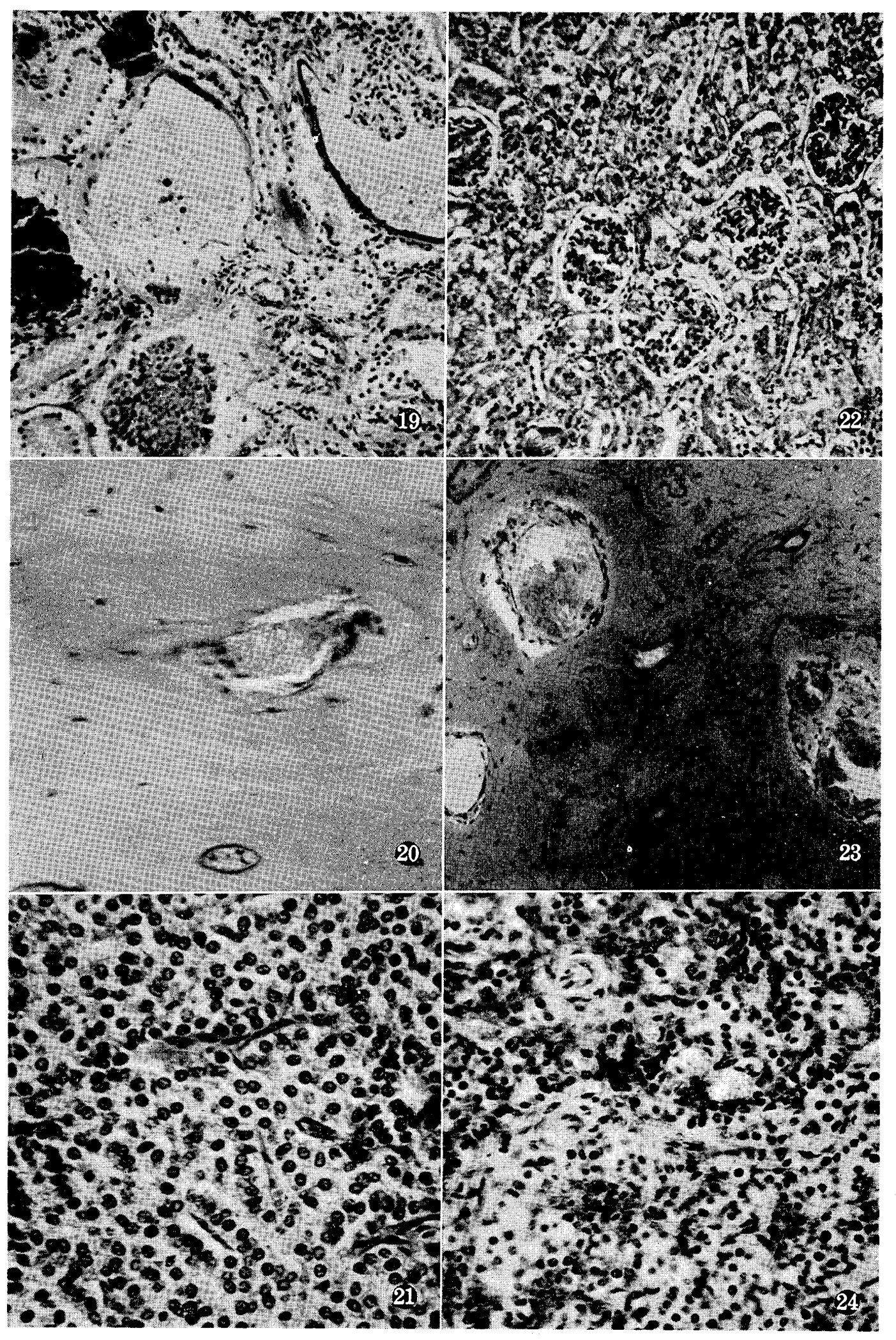

